NIH's budget. A major fight in Congress can be expected.

Agriculture

Hopes for a $\$ 100$ million competitive grants programme have evaporated. Last year, the Reagan administration managed against all odds to secure almost the full authorized level of $\$ 50$ million for this programme, the only alternative to the automatic formula-funding to the land-grant colleges and the agency's in-house Agricultural Research Service (ARS). With the farm bill up for renewal this year, there was talk of pressing an expanded programme that would become the major mechanism for supporting agricultural research. Instead, the administration is proposing to hold the programme at its present level of $\$ 46$ million. ARS is to be cut by 2 per cent, to $\$ 485$ million; formula funds will be held at last year's level of $\$ 258$ million.

Aeronautics and Space

The space station continues to dominate NASA's research and development programme, jumping to $\$ 220$ million from the present $\$ 140$ million. Physics and astronomy are due for a 10 per cent cut, planetary exploration for an 18 per cent increase. But these changes appear to reflect an overall decision to maintain previous commitments while not starting anything substantially new. Galileo and the Space Telescope are due for launch in 1986; work will continue as planned on the Venus Radar Mapper, the Mars Geoscience/Climatology Orbiter, the Gamma-Ray Obser-

vatory, the Explorer series of satellites and the Upper Atmosphere Research Satellite. Efforts to promote space commercialization will be boosted more than threefold, to $\$ 40$ million.

Energy

An overall 2 per cent cut is planned for the Department of Energy; following the wellworn Reagan Administration path, these cuts will come in magnetic fusion, solar and fossil programmes. But this time cuts are due in fission research as well, and even in basic research. The high-energy physics budget is to fall by $\$ 35$ million, to $\$ 510$ million; nuclear physics is to fall by 4 per cent, to $\$ 173$ million.

No new major facilities will be started in 1986, although there is a small request for funds to support research into future accelerator designs. The capital equipment request will provide "only the highest priority needs" for instrumentation at the Stanford Linear Collider and the Fermilab Tevatron accelerators now nearing completion. Preparatory work on the Continuous Electron Beam Accelerator Facility at Newport News, Virginia, is to continue.

Magnetic fusion is to take a major cut, however, from $\$ 434$ million to $\$ 390$ million. Fission research, which includes breeder reactor technology, will fall by 8 per cent. And alternative energy programmes are due for the annual Reagan attempt at virtual elimination.

Stephen Budiansky \& Tim Beardsley

\section{More for star wars}

\section{Washington}

TRUE to its avowed policy of strengthening national defence, the administration's budget request for the Department of Defense is up by $\$ 29,000$ million, to $\$ 323,000$ million. The defence proposals can be expected to have a rough passage through Congress, however, and the department's 1986 budget plan might look rather different by the start of the fiscal year next October.

The administration is looking for a 22 per cent increase in defence-related research and development, bringing the total to $\$ 39,400$ million, or 50 per cent above the 1984 level (see graph). If the administration gets its way, the Defense Department will account for 65 per cent of total federal expenditure on research and development, estimated at $\$ 60,000$ million.

Basic research will be increased by 16 per cent to $\$ 962$ million, and there will be an "increased emphasis" on the development of a ballistic missile defence system - the Strategic Defense Initiative (SDI), better known as "Star Wars". Total proposed

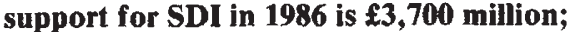
topics listed include space surveillance and target acquisition, directed energy and kinetic energy weapons battle management systems and system survivability.

Other major research and development projects are mentioned: the Small Intercontinental Ballistic Missile or Midgetman, with its hardened mobile launcher; the Trident II strategic missile; the MX missile, deployment of which is counted "essential"; and the Advanced Tactical Bomber.

Tim Beardsley

Expenditure on Strategic Defence Initiative (\$ million)

Surveillance, acquisition, tracking and kill assessment

Directed-energy weapons

Kinetic-energy weapons*

Systems concepts and battle management

Survivability, lethality and support

Total

$\begin{array}{rr}1985 & 1986 \\ 546 & 1,386 \\ 376 & 965 \\ 256 & 860 \\ 99 & 243 \\ 112 & 258 \\ 1,389 & 3,712\end{array}$

*This includes rail guns and new technology, as well as incorporating the high-velocity rocket programmes that had been part of the Army's old ABM programme for defending ICBM sites.
National Science Foundation Board plans
more active role

\section{Washington}

THE US National Science Board, the policymaking body of the National Science Foundation (NSF), last week took steps to increase its effectiveness in strategic planning. The hope is that, by wasting less time rubber-stamping grants that have already been approved in principle, the 24-member board will spend more time on identifying future scientific needs.

Constitutionally, the relationship between the board and NSF is anomalous, one that does not function well within the US government. In title supervisory, the board is composed of part-time people who cannot hope to keep on top of the fulltimers at NSF and who cannot pretend to give them directions without causing trouble. Only rarely in the past three decades have the board chairman and the NSF director been eager for a symbiotic relationship, with the board functioning as a high-level lobbyist. But that the time may have come.

The science board, hitherto widely regarded as having been rather ineffectual, is required by law to approve all NSF programmes entailing a new commitment of $\$ 2$ million or more, or the spending of more than $\$ 500,000$ in one year. Despite inflation in science as elsewhere, these dollar amounts have not changed since 1968, so much time is now spent reviewing individual grants in the high-spending areas. In future, however, the board will delegate routine renewals to NSF director Erich Bloch; Congress will be asked to remove legal obstacles standing in the way.

The new initiative, which also involves a thorough shake-up of the science board's committee structure, has been instigated jointly by Bloch and Dr Roland Schmitt, chairman of the science board. Both men have brought big-business experience to their positions and the organizational changes are seen as a reflection of this. While the changes will not immediately affect most active scientists, prudent heads of research institutes will want to pay close attention to science board plans to give special support to deserving subject areas, according to Leonard Redecke, executive secretary to the NSF programmes council. A new committee of the science board will give increased prominence to the interests of minority groups.

There could yet be some troublesome legal obstacles, however. The NSF reauthorization bill would be the obvious way for Congress to make the changes to the National Science Foundation Act that NSF is now requesting but, because of a jurisdictional dispute between two Senate committees, NSF has not been reauthorized for the past four years. No early solution of that dispute is in prospect. 